\title{
Implementasi Trainer PLC Guna Pembelajaran Mekatronika Di Akademi Angkatan Udara
}

\author{
(PLC Trainer Implementation To Learn Mechatronics \\ In The Air Force Academy )
}

\author{
Bambang Gastomo $^{1}$, Edi Supartono², Muhammad Fahrurozi ${ }^{3}$ \\ 1,2,3 Program Studi Elektronika Pertahanan, Akademi Angkatan Udara \\ E-mail: bambang.gastomo@aau.ac.id,ed.supartono@aau.ac.id,muhammad.fahrurozi@aau.ac.id
}

\begin{abstract}
The implementation of mechatronics learning packaged in the form of a PLC trainer goes through several stages including: needs analysis, model design, implementation, product testing and revision. Overall, the feasibility of PLC trainers based on the results of the feasibility test, namely the validation of media experts was declared very feasible with a percentage of $86.67 \%$, material expert validation was declared very feasible with a percentage of $88.33 \%$, while in the pretest and posttest with an average pretest value of 67,19 and post test 72,72. The results of the t-test stated that the value of tcount > ttable $(8.288>2.042)$ and significance $(0.000<0.05)$, meaning that there was a significant difference in the average score of pretest and posttest cadets learning achievement scores with an increase in the learning percentage of $82.30 \%$. It can be concluded that the implementation of the PLC trainer for teaching mechatronics is included in the very good category and is worthy of being used as a learning medium in order to improve AAU's student outcomes.
\end{abstract}

Keywords - PLC trainer implementation, Mechatronics Learning

Abstrak - Implementasi pembelajaran mekatronika yang dikemas dalam bentuk trainer PLC melalui beberapa tahapan meliputi : Analisis kebutuhan, Perancangan model, Implementasi, Pengujian dan Revisi Produk. Secara keseluruhan kelayakan trainer PLC berdasarkan hasil uji kelayakan yaitu validasi ahli media dinyatakan sangat layak dengan persentase bernilai 86,67\%, validasi ahli materi dinyatakan sangat layak dengan persentase bernilai 88,33\%, sedangkan dalam pretest dan posttest dengan nilai rata-rata pretest 67,19 dan post test 72,72. Hasil uji-t menyatakan nilai thitung > ttabel $(8,288>2,042)$ dan signifikansi $(0,000<0,05)$, artinya terdapat perbedaan yang signifikan rata-rata skor nilai prestasi belajar Taruna pretest dengan posttest dengan peningkatan persentase belajar 82,30 \%. Hal ini dapat disimpulkan bahwa implementasi trainer PLC pengajaran mekatronika ini termasuk dalam kategori sangat baik dan layak digunakan sebagai media pembelajaran dalam rangka untuk meningkatkan hasil didik $A A U$.

Kata Kunci- Implementasi trainer PLC, Pembelajaran Mekatronika

\section{Pendahuluan}

Pendidikan diarahkan agar Taruna tidak hanya memiliki kemampuan dibidang ilmu pengetahuan dan teknologi, tetapi juga dalam rangka terbentuknya prajurit matra udara yang berkepribadian dan berwatak ksatria serta berkualitas sehingga siap melaksanakan

*Penulis Korespondensi (Bambang Gastomo)
E-mail: bambang.gastomo@aau.ac.id 
penugasan-penugasan dikemudian hari. Berdasarkan kurikulum AAU 2018 terdapat pelajaran bidang studi mekatronika dan mengacu pada kompetensi keahlian dan level kualifikasi keahlian maka proses pembelajaran dituntut untuk mampu memberikan keterampilan berkarya bagi setiap peserta didik. Kenyataan yang ada di AAU, belum optimalnya komponen praktikum untuk mekatronika, hal tersebut merupakan salah satu kendala untuk menghasilkan hasil didik yang profesional dalam hal penguasaan ilmu pengetahuan dan teknologi.

Keberhasilan pendidikan dalam menghasilkan lulusan yang mempunyai keahlian, dipengaruhi oleh mutu pendidikan. Lebih lanjut bahwa lulusan AAU memiliki kemampuan yang belum siap bekerja adalah dengan memberikan lebih banyak praktik dibanding teori. Melalui penelitian ini, harapannya adalah dapat memberikan gambaran tentang model pendekatan pembelajaran praktik menggunakan trainer PLC yang dapat diimplementasikan pada sistem pembelajaran mekatronika.

\section{LANDASAN TEORI}

\section{A. Tinjauan Pustaka}

Beberapa naskah atau karya Ilmiah yang sesuai dengan penelitian ini antara lain:

1. Irvan Indrawan 2013 [1]. Dari penelitian ini dapat diambil kesimpulan bahwa modul latih ini dapat digunakan pemula untuk meningkatkan pemahamannya tentang sistem kontrol waktu nyata dan melatih keterampilan dalam pembuatan program.

2. Bayu Pujo Leksono dan Sumardi 2011 [2]. Sehingga pembelajaran tentang perancangan $P L C$ sangat diperlukan. Dalam perancangan sistem ini diperlukan beberapa pengetahuan dasar baik itu untuk PLC Sehinggga pemahaman seperti interface I/O PLC dengan perangkat keras, disusul, kemudian dengan pemahaman tentang diagram lader dan pemahaman tentang plants sangat diperlukan dalam merancang SCADA.

3. Puput Winarti Rusimamto 2013 [3]. Pada penelitian pengembangan ketrampilan mahasiswa. Salah satu caranya dengan menyusun pengembangan modul ajar dan alat peraga teknik pengaturan menggunakan perangkat lunak matlab dengan inquiry based learning.

\section{B. Pengertian Media Pembelajaran Computer Assisted Instruction (CAI)}

Pengertian Media Pembelajaran Computer Assisted Instruction (CAI) - Media Computer Assisted Instruction (CAI) yang pada dasarnya media berbasis komputer terdapat didalamnya, "CBI (Computer Based instruction) yaitu penggunaan komputer secara luas yang bisa dimanfaatkan tidak hanya sebagai fungsi $C A I$, juga dimanfaatkan dengan fungsi sistem pembelajaran individual". Keluasan penggunaan media komputer tergantung dari penggunaan program atau perangkat lunak yang terdapat di dalam komputer itu sendiri.

" $C A I$ adalah suatu sistem penyampaian materi pelajaran yang berbasis mikroprosesor yang pelajarannya dirancang dan diprogram ke dalam sistem tersebut melalui media CAI (Computer Assisted Instruction), materi dikemas menjadi lebih menarik dalam proses pembelajaran"[4].

\section{Sistem Kendali}

Sistem kendali dalam teknik listrik mempunyai arti suatu peralatan atau sekelompok peralatan yang digunakan untuk mengatur fungsi kerja suatu mesin dan memetakan tingkah laku mesin tersebut sesuai dengan yang dikehendaki. Fungsi kerja mesin tersebut mencakup antara 
lain menjalankan (start), mengatur (regulasi), dan menghentikan suatu proses kerja. Pada umumnya, sistem kendali merupakan suatu kumpulan peralatan listrik atau elektronik, peralatan mekanik, dan peralatan lain yang menjamin stabilitas dan transisi halus serta ketepatan suatu proses kerja. Sistem kendali mempunyai tiga unsur yaitu input, proses, dan output. Input pada umumnya berupa sinyal dari sebuah transduser, yaitu alat yang dapat merubah besaran fisik menjadi besaran listrik, misalnya tombol tekan, saklar batas, termostat, dan lain-lain. Transduser memberikan informasi mengenai besaran yang diukur, kemudian informasi ini diproses oleh bagian proses. Bagian proses dapat berupa rangkaian kendali yang menggunakan peralatan yang dirangkai secara listrik, atau juga berupa suatu sistem kendali yang dapat diprogram yaitu PLC. Pemrosesan informasi (sinyal input) menghasilkan sinyal output yang selanjutnya digunakan untuk mengaktifkan aktuator (peralatan output) yang dapat berupa motor listrik, kontaktor, katup solenoid, lampu, dan sebagainya. Dengan peralatan output, besaran listrik diubah kembali menjadi besaran fisik. Sistem kendali dibedakan menjadi dua, yaitu sistem kendali loop terbuka dan sistem kendali loop tertutup.[5]

\section{PLC Programmable Logic Controller)}

PLC didefinisikan sebagasi suatu perangkat elektronik digital dengan memori yang dapat diprogram untuk menyimpan instruksi-instruksi yang menjalankan fungsi-fungsi spesifik seperti: logika, sekuen, timing, counting, dan aritmatika untuk mengontrol suatu mesin industri atau proses industri sesuai dengan yang diinginkan. PLC mampu mengerjakan suatu proses terus menerus sesuai variabel masukan dan memberikan keputusan sesuai keinginan pemrograman sehingga nilai keluaran tetap terkontrol[6].

\section{E. PLC Mitsubishi FXOS-20 MT-D}

Berdasarkan gambar spesifikasi diatas PLC Mitsubishi FXOS-20 MT terdiri 8 buah masukan, 12 buah keluaran, dengan tegangan nominal 24 Volt DC, dengan berat 0,35 $\mathrm{Kg}$ [7].

TABEL I

Spesifikasi $P L C$ Mitsubishi FX0s

\begin{tabular}{|c|c|c|c|c|c|c|c|c|c|c|}
\hline \multirow{2}{*}{$M O D E L$} & \multicolumn{3}{|c|}{ OUTPUT TYPE } & \multicolumn{2}{|c|}{ INPUTS 24 Vdc } & \multirow{2}{*}{$\begin{array}{l}\text { POWER } \\
\text { SUPPLY }\end{array}$} & \multirow{2}{*}{\multicolumn{3}{|c|}{$\begin{array}{c}\text { DIMENSION } \\
\text { Mm(inch) }\end{array}$}} & \multirow{3}{*}{$\begin{array}{c}\text { Weight } \\
\text { Kg(libs) } \\
0.33 \\
(0.66)\end{array}$} \\
\hline & RELAI & $\operatorname{Tr}$ & $Q T Y$ & $Q T Y$ & $T Y P E$ & & & & & \\
\hline$F X-14$ & \multirow{6}{*}{$M R-05$} & \multirow{6}{*}{$\begin{array}{l}\text { MT-DSS } \\
\text { (SOURCE) }\end{array}$} & 6 & 8 & \multirow{6}{*}{$\begin{array}{c}\text { SINK } \\
\text { (SOURCE) }\end{array}$} & \multirow{3}{*}{$\begin{array}{c}24 V D C \\
+10 \% \\
-15 \%\end{array}$} & $\begin{array}{l}100 \\
(3.9)\end{array}$ & \multirow{3}{*}{$\begin{array}{c}80 \\
(3.1)\end{array}$} & \multirow{3}{*}{$\begin{array}{c}47 \\
(1.9)\end{array}$} & \\
\hline$F X-20$ & & & 8 & 12 & & & $\begin{array}{c}130 \\
(5.1) \\
\end{array}$ & & & $\begin{array}{c}0.35 \\
(0.77) \\
\end{array}$ \\
\hline$F X-30$ & & & 14 & 16 & & & $\begin{array}{l}170 \\
(6.7)\end{array}$ & & & $\begin{array}{c}0.40 \\
(0.88)\end{array}$ \\
\hline$F X-34$ & & & 10 & 14 & & \multirow{3}{*}{$\begin{array}{c}24 V D C \\
+20 \% \\
-15 \%\end{array}$} & $\begin{array}{c}130 \\
(5.1)\end{array}$ & \multirow{3}{*}{$\begin{array}{c}80 \\
(3.5)\end{array}$} & \multirow{3}{*}{$\begin{array}{c}87 \\
(3.4)\end{array}$} & $\begin{array}{c}0.60 \\
(1.32) \\
\end{array}$ \\
\hline$F X-40$ & & & 16 & 24 & & & $\begin{array}{l}150 \\
(5.9)\end{array}$ & & & $\begin{array}{c}0.75 \\
(1.65)\end{array}$ \\
\hline$F X-60$ & & & 24 & 36 & & & $\begin{array}{l}185 \\
(7.3)\end{array}$ & & & $\begin{array}{c}0.90 \\
(1.98)\end{array}$ \\
\hline$F X-14$ & & \multirow{3}{*}{$\begin{array}{c}M T-D / E \\
(S I N K)\end{array}$} & 6 & 8 & \multirow{3}{*}{ SINK } & \multirow{3}{*}{$\begin{array}{c}24 V D C \\
+10 \% \\
-15 \%\end{array}$} & $\begin{array}{l}100 \\
(3.9)\end{array}$ & \multirow{3}{*}{$\begin{array}{c}80 \\
(3.1)\end{array}$} & \multirow{3}{*}{$\begin{array}{c}47 \\
(1.9)\end{array}$} & $\begin{array}{c}0.3 \\
(0.66)\end{array}$ \\
\hline$F X-20$ & & & 8 & 12 & & & $\begin{array}{c}130 \\
(5.1)\end{array}$ & & & $\begin{array}{c}0.35 \\
(0.77) \\
\end{array}$ \\
\hline$F X-30$ & & & 14 & 16 & & & $\begin{array}{l}170 \\
(6.7)\end{array}$ & & & $\begin{array}{c}0.40 \\
(0.88)\end{array}$ \\
\hline
\end{tabular}

\section{F. $H M I$}

$H M I$ adalah subsistem dari SCADA yang berfungsi menampilkan data dari hasil pengukuran ataupun menampilkan proses yang sedang terjadi pada keseluruhan sistem. $H M I$ merupakan sebuah software pada komputer berbasis grafis yang berfungsi untuk mempermudah pengawasan (Supervisory) kepada sang operator. HMI mengubah data-data dan angka kedalam animasi, grafik/trend, dan bentuk yang mudah diterjemahkan oleh sang 
operator, banyak contoh program yang berbasis $H M I$ contohnya Wonderware, WinCC, dan masih banyak lagi[8].

\section{G. Relay}

Relay adalah sebuah alat elektromagnetik yang dapat mengubah kontak-kontak saklar sewaktu alat ini menerima sinyal listrik. Relay merupakan piranti elektromagnetis yang telah digunakan dalam penerapan yang sangat luas. Alat ini tersusun atas sebuah kumparan kawat beserta sebuah inti besi lunak. Relay DC 24 V MK3P-1 (OMRON)[9].

\section{H. Catu Daya}

Catu daya diperlukan untuk dapat menghasilkan tegangan tertentu. Rangkaian catu daya tersusun dari sebuah transformator penurun tegangan, diode penyearah, kapasitor penghilang ripple, dan IC regulator. Prinsip kerja dari catu daya adalah tegangan sumber $(A C)$ diturunkan dengan trafo step down, kemudian disearahkan dengan dioda, diratakan dengan kapasitor sebagai filter, dan distabilkan dengan IC regulator[10].

\section{GX Programmer Ver 8.0 dan GT Works 3}

Software yang digunakan pada penelitian ini adalah GX Programmer Ver. 8.0 dan GT Works 3 (Disigner dan Simulation Ver.3.1). GX Programmer Ver 8 merupakan sebuah software pemrograman PLC dan GT Works 3 untuk membuat, memonitor dan mensimulasi rancangan scada PLC Mitsubishi[11].

\section{Metodologi Penelitian}

Metode penelitian yang digunakan dalam penelitian menggunakan metode penelitian dan pengembangan atau Research and Development $(R \& D)$ dengan model pengembangan ADDIE (Analysis, Design, Development, Implementation, and Evaluation) .

Metodologi Penelitian dalam implementasi trainer PLC guna media pembelajaran mekatronika di AAU secara garis besar terdiri atas analisis kebutuhan, perancangan, implementasi, pengujian dan validasi. Maka fokus penelitian ini antara lain : (1) Mengetahui unjuk kerja trainer PLC; (2) Mengetahui kelayakan trainer PLC sebagai media pembelajaran ; (3) Mengetahui efektivitas media pembelajaran mekatronika yang dikembangkan untuk pembelajaran $P L C$ oleh Taruna AAU.

Penelitian ini dilakukan di Depertemen Elektronika AAU Laboratorium Sistem Pengaturan Yogyakarta yang beralamat di Jalan Solo Jogja km.10 Telp./Fax 0274-(552198), DIY. Populasi yang digunakan dalam penelitian ini adalah Taruna Tingkat 4 yang sedang menempuh semester 7. Sampel yang diambil yaitu pada Taruna Tingkat IV Mayoring Elektronika Pertahanan yang berjumlah 33 0rang.

Prosedur penelitian yang dilakukan mengikuti metodologi pengembangan media pembelajaran $P L C$ yang diadaptasi, yakni meliputi lima tahapan yaitu Tahap Pengumpulan Data, Tahap Desain, Tahap Pengembangan, Tahap Implementasi, Tahap Pengujian (Testing) dan Penilaian.

Metode yang digunakan untuk menganalisis data adalah dengan teknik analisis deskriptif kuantitatif yang diungkapkan dalam skor skala lima (skala linkert). Implementasi dari media 
pembelajaran ini dilanjutkan dengan uji efektifitas produk menggunakan metode preeksperimental design yaitu onegroup pretest-posttest design.

Pengumpulan data dilakukan dengan melalui empat tahapan yaitu :

1. Pengujian dan Pengamatan

Pengujian dan pengamatan ini dimaksudkan untuk mengetahui unjuk kerja modul trainer PLC sebagai modul praktikum mekatronika dengan validasi dari ahli media dan ahli materi.

2. Kuesioner dengan menggunakan 5 skala Likert $(1,2,3,4,5)$. Kuesioner tersebut digunakan untuk menguji kelayakan produk prototipe trainer PLC.

3. Observasi, digunakan untuk mengetahui aspek-aspek teknis kualitas dilihat dari tingkat efektivitas pemanfaatan media pembelajaran $P L C$.

4. Instrumen Penelitian, Instrumen yang digunakan dalam penelitian adalah angket, tabel checklist hasil pengujian. Instrumen penelitian khususnya untuk melihat ketepatan konten media dan instrument kelayakan media pembelajaran yang dibangun. Untuk menyempurnakan instrumen penelitian, dilakukan validitas konstruk melalui pendapat pakar, yakni dengan cara experts judgement. Instrumen ini digunakan untuk mengetahui seberapa layak media untuk pengajaran mekatronika yang dikemas dalam bentuk trainer $P L C$.

\section{HASIL DAN PEMBAHASAN}

\section{A. Hasil Desain Hardware Trainer PLC}

Desain trainer diwujudkan dalam beberapa rangkaian elektronik yang merupakan komponen penyusun rangkaian $P L C$ dan rangkaian output. Perancangan trainer PLC terdiri dari beberapa bagian yaitu : (1) rangkaian input, (2) Rangkaian PLC, (3) Rangkaian output, (5) Rangkaian power supply. Trainer juga dilengkapi dengan saklar toggle, push buthon, Motor DC dan LED yang terpasang pada trainer sehingga setiap komponen pada trainer dapat dengan mudah di pasang dan diperbaiki apabila ada komponen yang rusak. Tata letak komponen diatur sesuai lay out diagram dan dibuat posisi modul rangkaian di letakkan pada bahan arclic untuk memudahkan pengoperasian.

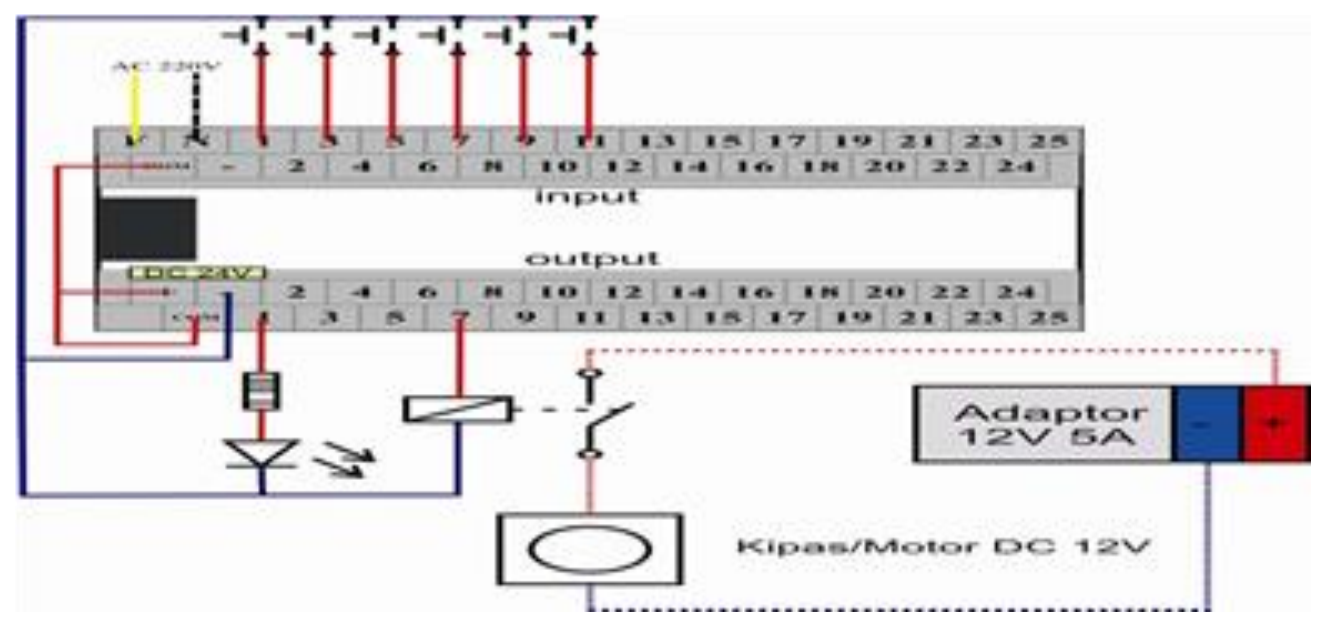

Gambar 1. Lay out Trainer PLC 


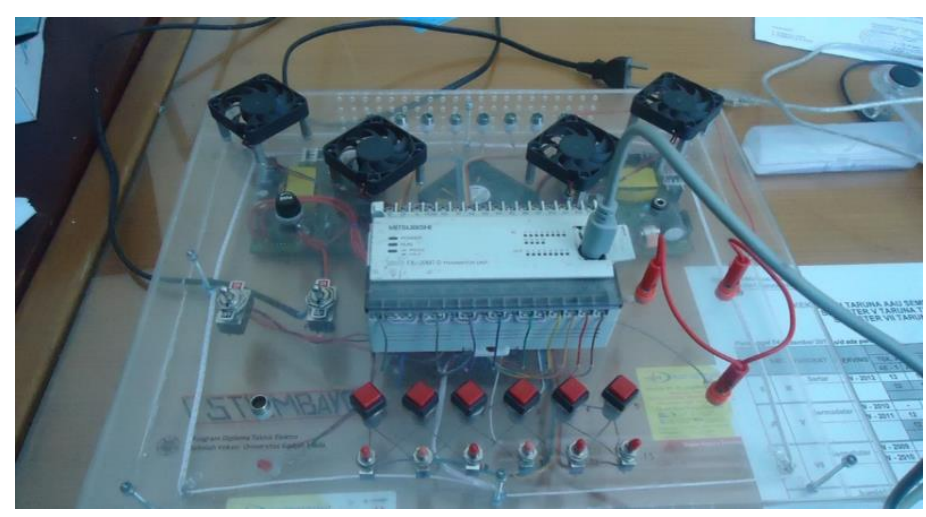

Gambar 2. Trainer PLC

\section{B. Hasil Implementasi Software}

Proses pembuatan kode program merupakan proses implementasi atau proses penulisan kode program dengan menggunakan GX Developer Ver.8 dengan diagram alir (flow chart) yang ditetapkan pada langkah desain. Dalam koding juga dibuat antarmuka sistem PLC dan simulasi SCADA menggunakan program GT Works 3 (GT Designer dan GT Simulator) untuk aplikasi $H M I$ memudahkan interaksi antara manusia dan mesin.

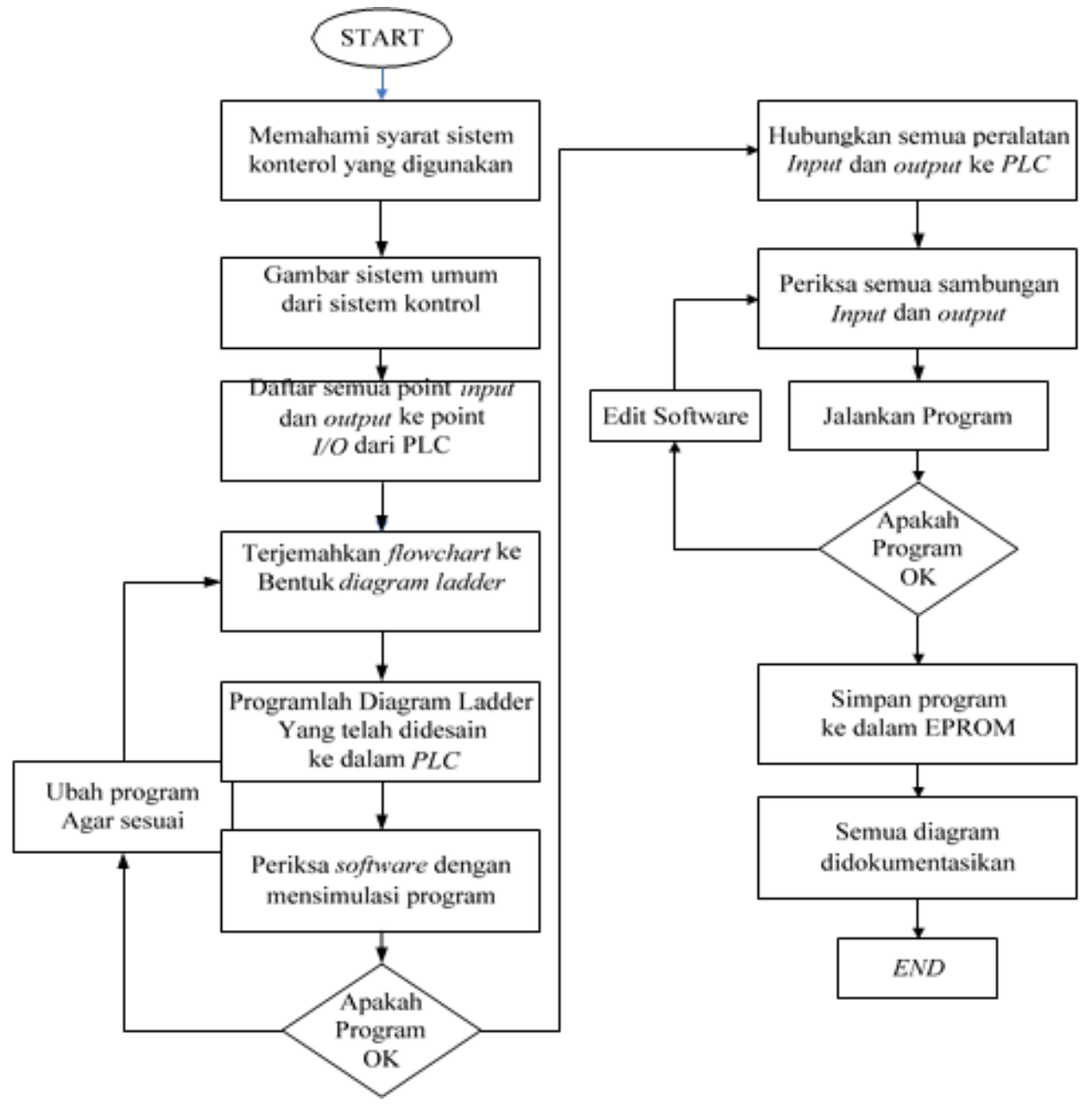

Gambar 3. Flowchart Perancangan Sistem Kontrol PLC 


\section{Pembahasan}

Berdasarkan hasil implementasi dan saran-saran yang diberikan, baik dari ahli media maupun ahli materi maka dilakukan perbaikan media melalui dua tahap,yakni tahap perancangan media pembelajaran dan tahap perancangan program aplikasi otomasi industri.

Tingkat kelayakan media pembelajaran berupa trainer PLC dalam penelitian ini menggunakan instrumen penelitian yang telah di Expert Judgment oleh ahli materi pembelajaran dan ahli media pembelajaran.

\section{Validasi Isi (Content Validity)}

Uji validasi isi dibagi menjadi dua aspek penilaian yaitu kualitas materi dan kemanfaatan. Berdasarkan hasil penelitian perolehan persentase aspek Kualitas Materi sebesar 86.67\%, sedangkan aspek Kemanfaatan memperoleh $90.00 \%$. Dari kedua aspek tersebut didapatkan persentase keseluruhan dari validasi isi materi yaitu sebesar $88.33 \%$. Dengan demikian tingkat validasi isi materi trainer PLC sebagai media pembelajaran dikatagorikan sangat layak.

\section{Validasi konstrak (Construct Validity)}

Uji validasi konstrak dibagi menjadi tiga aspek penilaian yaitu keefektifan desain tampilan, teknis dan kemanfaatan. Berdasarkan hasil penelitian perolehan persentase aspek keefektifan desain tampilan sebesar $86.67 \%$, sedangkan aspek Teknis memperoleh $85.00 \%$ dan aspek Kemanfaatan memperoleh $88.33 \%$. Dari ketiga aspek tersebut didapatkan persentase keseluruhan dari validasi konstrak yaitu sebesar 86.67\%. Dengan demikian tingkat validasi konstrak trainer PLC sebagai media pembelajaran dikatagorikan sangat layak.

\section{Validasi ujicoba pemakaian}

Tingkat validasi pemakaian media pembelajaran berasal dari Taruna AAU Yogyakarta. Dari uji coba pemakaian oleh Taruna media pembelajaran ini memperoleh persentase $74,87 \%$. Dengan demikian tingkat validasi media pembelajaran ini dikatagorikan layak. Hasil analisis releabilitas instrumen dengan uji beta pengujian Taruna sebelum dan sesudah menggunakan trainer PLC .

\section{KESIMPULAN}

Berdasarkan hasil penelitian yang telah dilaksanakan bahwa: implementasi trainer PLC pengajaran mekatronika ini termasuk dalam kategori sangat baik dan layak digunakan sebagai media pembelajaran dalam rangka untuk memberikan bekal awal materi pengajaran mekatronika.. Hasil penelitian ini adalah produk dan kelayakan trainer PLC . Kelayakan trainer PLC berdasarkan hasil uji kelayakan yaitu (1) evaluasi validasi ahli media dinyatakan sangat layak dengan persentase bernilai $86,67 \%$, (2) validasi ahli materi dinyatakan sangat layak dengan persentase bernilai $88,33 \%$, (3) Sedangkan dalam pretest dan posttest dengan nilai ratarata pretest 67,19 dan post test 72,72 . Hasil uji-t menyatakan nilai thitung > ttabel $(8,288>$ $2,042)$ dan signifikansi $(0,000<0,05)$, artinya hipotesis $\mathrm{H} 1$ diterima terdapat perbedaan yang signifikan rata-rata skor nilai prestasi belajar Taruna pretest dengan posttest dengan peningkatan persentase belajar 82,30\%. Hasil validasi uji coba pemakaian media pembelajaran trainer PLC oleh Taruna AAU memperoleh persentase $74,87 \%$ artinya media pembelajaran ini dikatagorikan layak untuk pembelajaran praktik mekatronika.

Praktikum mekatronika diperlukan idealnya satu orang Taruna menggunakan satu $P C /$ laptop pada saat pembelajaran berlangsung, begitu pula dengan jumlah trainer PLC perlu untuk diperbanyak sehingga proses pembelajaran akan lebih baik. Hasil rancangan trainer PLC perlu disempurnakan dengan menambahkan konektor penghubung yang sesuai dengan standard antara trainer $P L C$ dan komputer/laptop, rancangan penopang modul rangkaian $P L C$ terbuat dari bahan akrilik kuat dan dibuat dudukan sesuai dengan ukuran dan berat $P L C$, komponenkomponen dibuat yang mudah didapatkan dipasaran memudahkan service dan maintenance. 


\section{UCAPAN TERIMA KASIH}

Ucapan terima kasih atas terbitnya naskah ini pada Seminar Nasional Sains Teknologi dan Inovasi Indonesia 2021 sebagai bagian kolaborasi/kerjasama penelitian antara [ UGM,UPN "Veteran" Yogyakarta ] dengan Akademi Angkatan Udara.

\section{REFERENSI}

[1] I. Indrawan, E. Haritman, dan D. L. Hakim, "Pembuatan Antarmuka Mesin Manusia Pada Modul Latih Plc Berbasis Perangkat Lunak Cx Designer," Penelit. Pendidik., vol. 338, 2013, Diakses: Okt 22, 2021. [Daring]. Tersedia pada: http://jurnal.upi.edu/penelitian pendidikan/view/2155/pembuatan-antarmuka-mesin-manusiapada-modul-latih-plc-berbasis-perangkat-lunak-cx-designer.html

[2] Bayu Pujo Leksono[1], Sumardi, S.T, M.T[2], "PERANCANGAN SISTEM SCADA PADA PLC OMRON CPM1A," Fak. Tek. Undip, 2013.

[3] Puput Wanarti Rusimamto1) Anita Qoiriah 1) Diah Wulandari 2), Totok Soehartanto3) Bambang Lelono, dan Widjiantoro3, "Pengembangan Modul Ajar teknik Pengaturan Menggunakan perangkat Lunak Matlab Dengan Inquary Based Learning Berorientasi Industri." Fakultas Teknik UNESA.

[4] D. K. Rusman dan C. Riyana, "Pembelajaran berbasis teknologi informasi dan komunikasi," Bdg. Rajawali Pers, 2011.

[5] "MODUL PRAKTIKUM WORKSOP PLC \& PNEUMATIK," hlm. 44.

[6] A. E. Putra, "PLC: Konsep, Pemrograman dan Aplikasi (Omron CPM1A/CPM2A dan ZEN Programmable Relay)," Yogyak. Penerbit Gava Media, 2004.

[7] "Melsec FX Family Programmable Logic Controllers Beginers Manual Mitshubishi."

[8] "Interaksi Manusia-Mesin," APLIGO. https://aplikasiergonomi.wordpress.com/tag/interaksi-manusia-mesin-2/ (diakses Okt 23, 2021).

[9] Program Diploma Teknik Elektro, Pelatihan PLC (Programmable Logic Controller). Yogyakarta: Sekolah Vokasi Universitas Gajah Mada, 2012.

[10] Widodo Sri Thomas, Elektronika Dasr. Jakarta: Salemba Teknik, 2002.

[11] H. Alam, H. Lubis, I. Parinduri, dan M. I. Z. Firdaus, Belajar PLC Menggunakan CX PROGRAMMER 9.1 dan ZELIO Soft2. Yayasan Kita Menulis, 2020. 